\title{
Ольга Редько
}

\section{ЯК МІСТА ПЕРЕЖИВАЛИ РЕВОЛЮЦІЮ? ДОКУМЕНТАЛЬНІ СВІДЧЕННЯ З ФОНДІВ ЦДАВО УКРАЇНИ}

$\Pi$ ереважна більшість документів про життєдіяльність міст та адміністрування ними відклалися в обласних та міських архівах. Утім і в Центральному державному архіві вищих органів влади та управління України зберігається понад 470 фондів місцевого самоврядування всіх державних утворень часів Української революції, серед яких (за приблизними підрахунками) - 26 міських адміністрацій. До прикладу можна навести деякі 3 них.

Серед документів Луганської міської управи (ф. 3049) зберігаються протоколи зборів та журнали засідань управи, відомості про збитки, заподіяні підприємству Товариства Луганських трубопрокатних заводів «Уніон» радянською владою тощо.

У фонді Кам'янець-Подільської міської управи (ф. 3143) відклалося листування з Кам'янець-Подільською єврейською управою, кооперативом «Якер» про ремонт єврейських національних шкіл, звільнення учнів від занять у школах в дні єврейських релігійних свят, внесення оплати за оренду приміщень тощо.

Фонд Харківського губернського старости (ф. 1325) серед іншого зберігає обіжники та листування про боротьбу із спекуляцією в м. Харкові та Харківській губернії, доповіді і рапорти про політичну ситуацію в містах та повітах губернії, про діяльність та фінансовий стан органів самоврядування тощо.

У документах Подільського губернського комісара Української Народної Республіки (ф. 538) знаходимо журнали засідань Кам'янець-Подільської міської думи. Серед документів Ради міністрів Української Держави (ф. 1064) зберігається положення про утворення міських дум і проведення виборів до них.

Протоколи засідань міських дум, губернських і повітових управ відклалися у фонді Міністерства внутрішніх справ Української Народної Республіки (ф. 1092).

У фонді 1115 (Українська Центральна Рада) відклалися документи про вибори до міських дум Волинської, Київської, Подільської, Полтавської, Чернігівської губерній.

Фонд Полтавського губернського комісара Тимчасового уряду, м. Полтава (ф. 2117) містить протокол засідань Полтавської міської думи, документи з питань організації роботи міліції; агентурні 
зведення про купівлю та продаж зброї; рапорти повітових старост про діяльність підпільних революційних організацій; документи про революційний переворот в м. Кременчуку.

Листування Товариства «Просвіта» ім. Т.Г. Шевченка у м. Києві з Київським міським головою про відкриття гімназії та інших просвітницьких установ, виділення коштів та надання приміщення відклалися у ф. 2217.

Листування з Миколаївською міською управою зберігається у ф. 2313 (Миколаївська рада об'єднаних українських організацій м. Миколаїв Херсонської губернії).

Тут необхідно зазначити, що в будь-якому фонді управлінської документації за 1917-1921рр. можна віднайти інформацію про діяльність міських адміністрацій. Проте більшості істориків у своїх дослідженнях з історії функціонування міського механізму не вдалося залучити їх у повному обсязі.

Існує хибне твердження, що всі документи зазначеного періоду вивчені користувачами. Спростовуємо фактами - дослідники, наприклад, вкрай рідко замовляють справи великого за обсягом фонду Державного сенату Української Держави, м. Київ (ф. 905). А серед документів фонду можна віднайти слідчі справи за касаційними скаргами установ, приватних власників та окремих громадян про продаж рухомого та нерухомого майна, закриття крамниць, право на здійснення торгівлі, знесення будівель, перевезення вантажу, виплату утримання на позашлюбних дітей, накладення арешту на локомобіль, збанкрутілих боржників тощо.

Чекають на своїх дослідників: справа про розгляд скарги Київського 2-го жіночого духовного училища на рішення Київської судової палати у справі позову до училища за нерухоме майно; справа Херсонського окружного суду про допит свідків у справі позову Петроградського міжнародного комерційного банку; скарга редактора «Одеського листка» на постанову головного крайового комісара Херсонщини, Таврії та Катеринославщини про запровадження попередньої цензури; справа про розгляд скарг Миколаївського міського громадського управління на ухвалу Херсонського окружного суду про відміну постанови Миколаївської міської думи про збір коштів для організації громадських робіт та їдалень; справа про розгляд скарги Товариства домовласників м. Києва та його передмість на постанову Київського окружного суду у справі оскарження товариством постанови Київської міської думи про встановлення оціночного та каналізаційного зборів; справа про розгляд скарги на постанову Кам'янець-Подільської міської думи про оподаткування промисловців та купців промисловим податком; справа про розгляд скарги Житомирської міської управи на постанову Житомирського окружного суду у справі оскарження постанови Житомирської міської думи про стягнення збору на утримання міліції; скарги громадян на постанову Київської міської думи від 10 липня 1917 р. про стягнення додаткового збору з нерухомого майна домовласників та багато інших.

Фонд 4146 (Державний сенат Української Народної Республіки, м Київ) також містить слідчі справи про розгляд скарг громадян на постанови міських дум і повітових управ. 
Зазначені фонди містять досить інформативні документи, в яких через призму судових процесів відстежується буденне життя мешканців міст у буремні роки.

Документи зазначених фондів досить інформативні, в них через призму судових процесів відображено, серед іншого, буденне життя мешканців міст.

Мало уваги дослідники приділяють фінансовим документам державних установ. Наприклад, у фонді Української Центральної Ради є доволі цікаві документи, з яких дізнаємося про вартість різних товарів та послуг у Києві 1917-1918 рр.

Цінність спогадів та щоденників багатьох українських діячів, що зберігаються у ЦДАВО України, визначається їхньою провідною роллю в описуваних подіях Української революції. М. Шаповал, С. Русова, А. Животко, Н. Григоріїв, Л. Білецький, В. Модзалевський, А. Андрієвський - це неповний перелік осіб, у споминах яких відбилися епізоди міського життя 1917-1921 рр. В особовому фонді Ю. Тищенка (Сірого) зберігаються автобіографічні історії дітей і підлітків, які через різні обставини змушені були залишити Україну. В них можна віднайти інформацію про пересування української армії і громадян та перебіг подій в населених пунктах.

Повсякденне життя міст в революційну добу відображається часом в найнеочікуваніших документах, i, що дуже важливо, ще чекає на свого дослідника. Міста та їх жителі, незважаючи на політичні потрясіння, продовжували купувати, продавати, скаржитись, вимагати та святкувати. Відповідні документи - не з категоpiї масових, а втім, не є і поодинокими.

Дана добірка сформувалась у процесі роботи над проектом «Календар Української революції», який реалізовується у ЦДАВО 3 березня 2017 р. Детальніше з ним можна ознайомитись за посиланням: http://tsdavo.gov.ua/4/webpages/64019454.html

Безперечно, що представлені документи не вповні ілюструють всі аспекти повсякдення містян у 1917-1918 рр. Але ставилась геть інша мета - показати, що ця сторона історичного минулого теж має своє архівне відображення і їй $є$ що розповісти.

У ЦДАВО України зберігається найбільша кількість особових фондів провідних постатей Української революції 1917-1921рр. В них часто можна знайти спогади українських діячів, в яких описані події 100-річної минувшини. Як приклад, представляємо уривок споминів Н. Григоріїва «В Український Центральній Раді» (Ф. 3262. Оп. 1. Спр. 22. Арк. 326-331), в якій автор надає характеристики відомим українським діячам і передає атмосферу, що панувала в Педагогічному музеї сто років назад. Яскравою ілюстрацією до цих спогадів є рахунок типографії товариства «Петро Барський» для Генерального секретарства внутрішніх справ за друкування плакатів «не плювати», «не курити» та «додержуватися тиші» (Ф. 1434. Оп. 1. Спр. 4. Арк. 23).

Так само детально Н. Григоріїв описує Київ у листопаді 1917 р. в статті «Усамостійнення України» (Ф. 3262. Оп. 1. Спр. 20. Арк. 172-182, 184-189). 


\section{ДЖЕРЕЛА ДО ІСтоРІї МІСт}

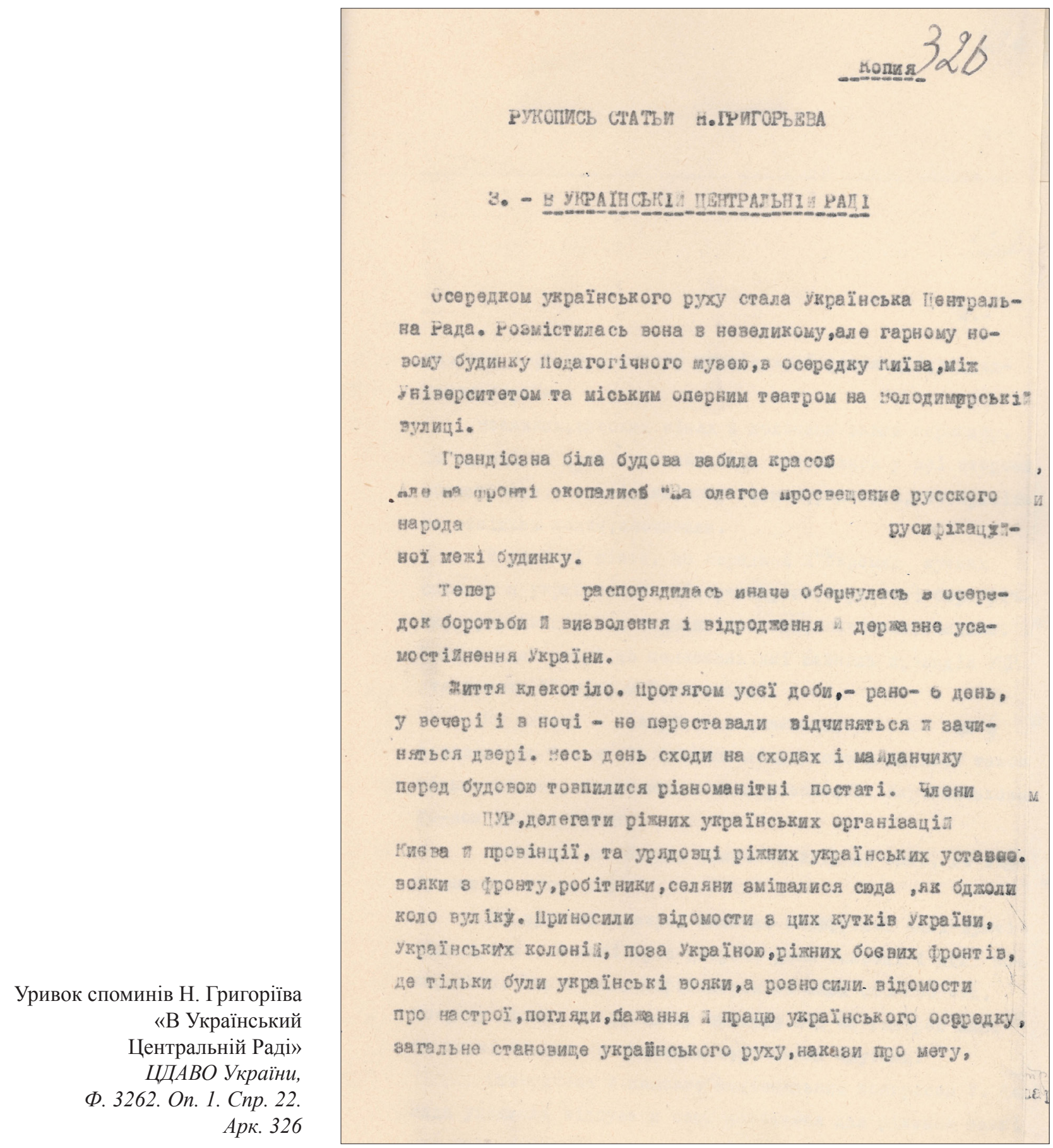




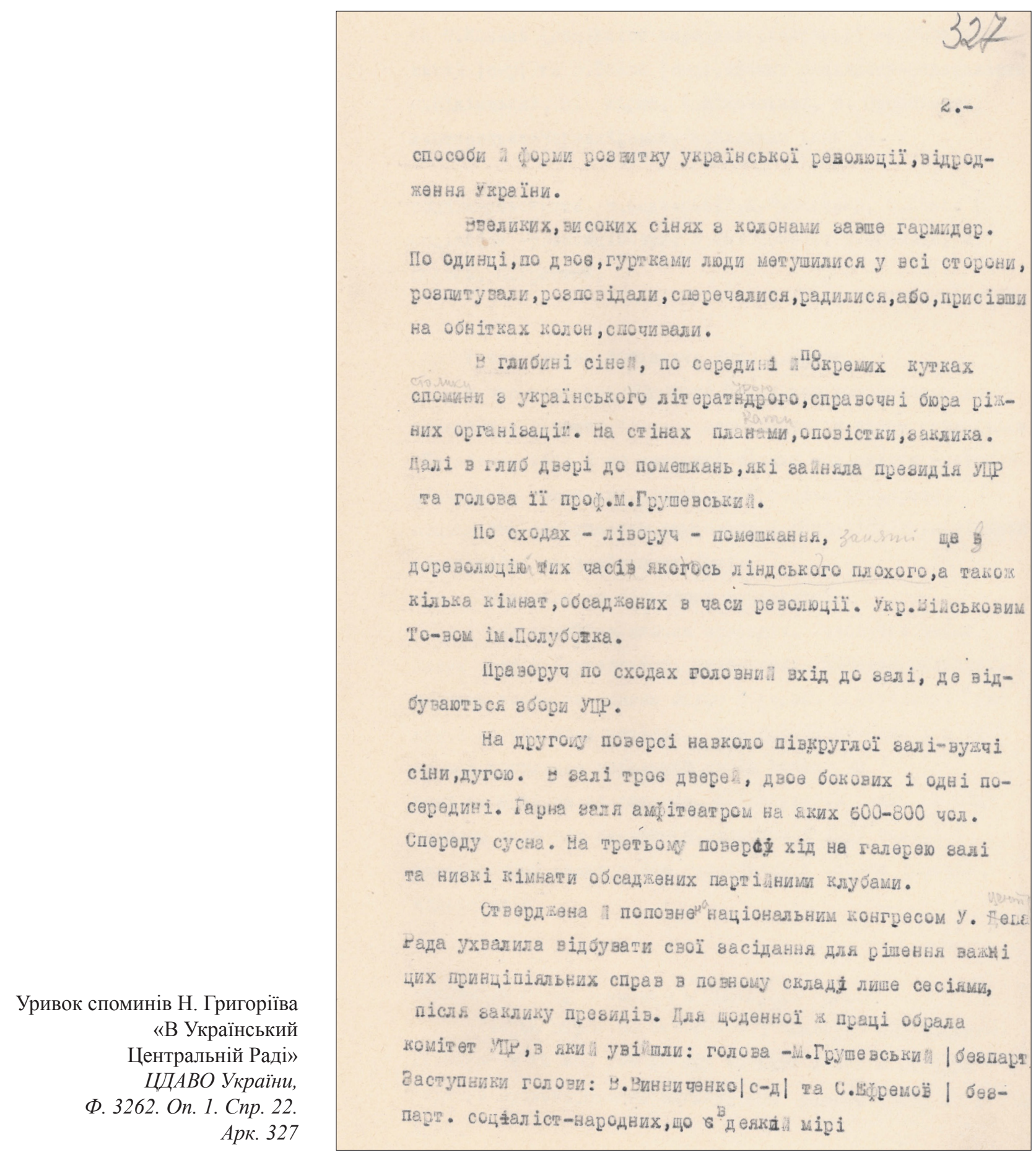




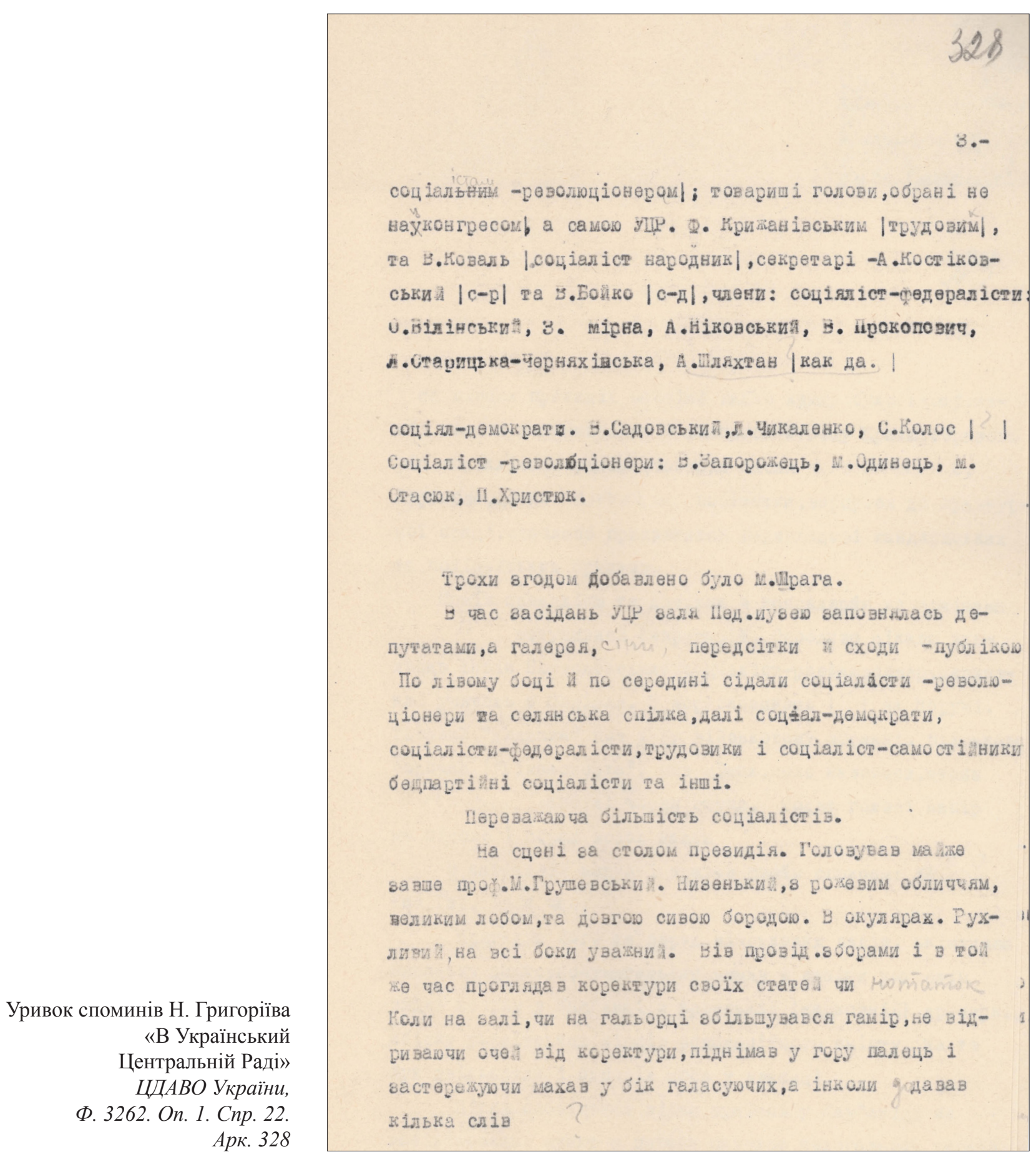




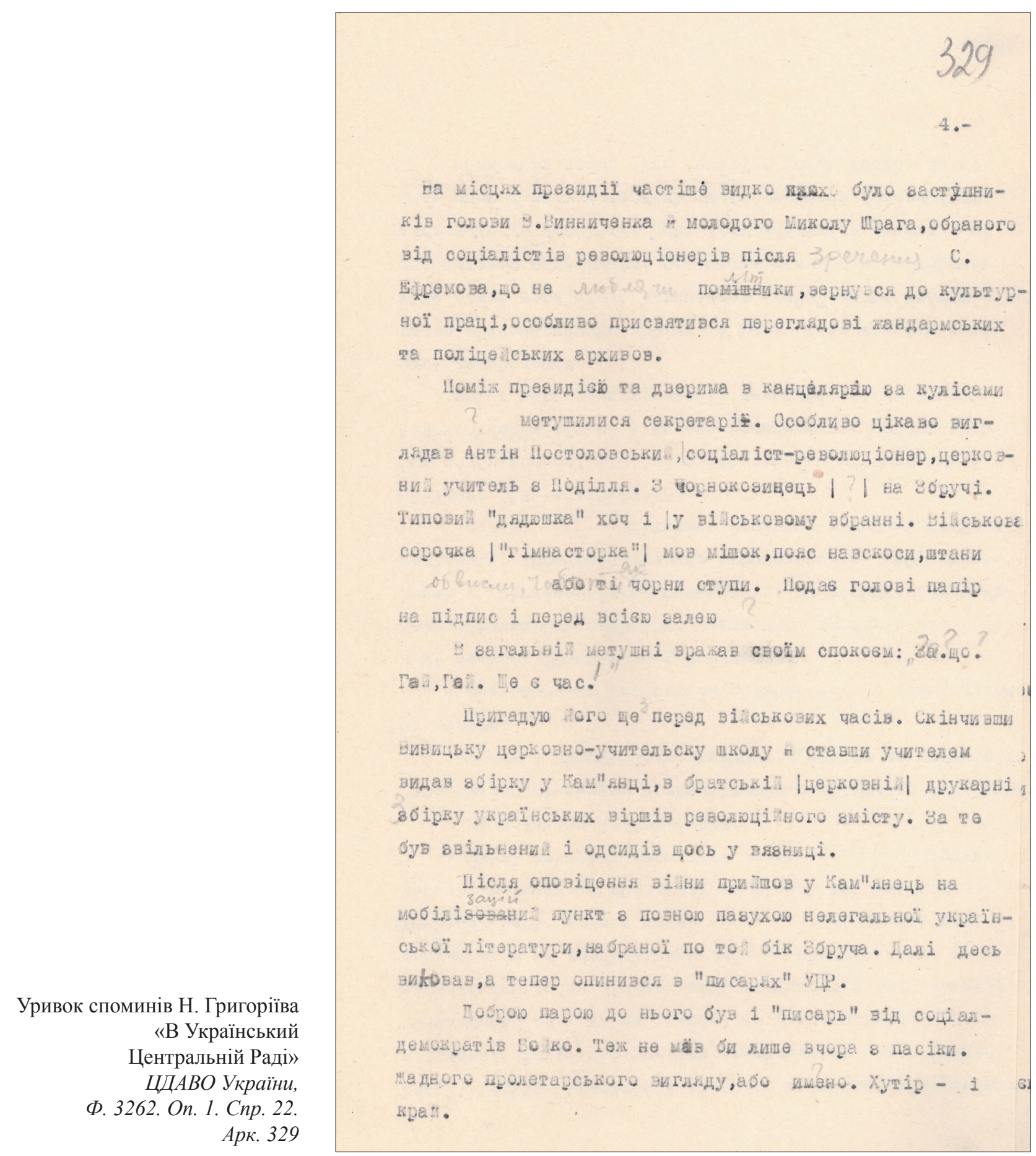




\section{ДЖЕРЕЛА ДО ІСтоРІї МІСт}

Уривок споминів Н. Григоріїва «В Український

Центральній Раді» ЦДАВО України, Ф. 3262. On. 1. Cnp. 22. Арк. 330

Рахунок типографії товариства «Петро Барський» для Генерального секретарства внутрішніх справ за друкування плакатів «не плювати», «не курити» та «додержуватися тиші» ЦДАВО Украӥни. Ф. 1434. On. 1. Сnр. 4. Арк. 23
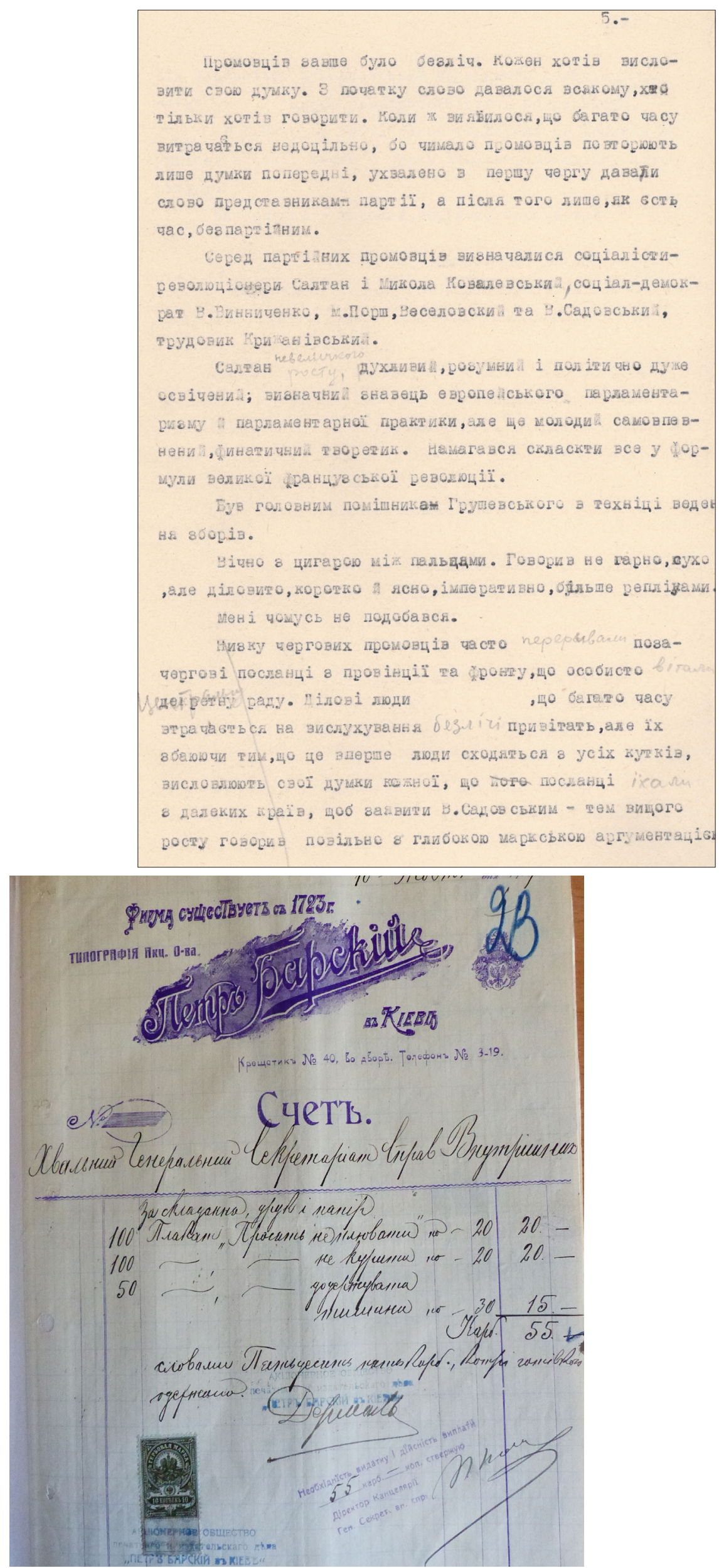
Окрему групу документів складають фінансові документи установ взагалі і Української Центральної Ради зокрема. Відібрані документи (рахунки з проставлянням цін) відображають, які фірми, товариства, майстерні та контори Києва надавали послуги та товари установам і населенню Києва (Ф. 1115. Оп. 1. Спр. 73, 74, 76). Серед них є досить інформативні: рахунки Київської будівельної контори «Граніт» для УЦР за вироблення цементного Українського гербу та зняття бронзового орла і ремонт будинку після попадання в нього снарядів (Ф. 1115. Оп. 1. Спр. 73. Арк. 79, 80); рахунок Київського міського електричного підприємства за споживання електроенергії Українською Центральною Радою в січні-лютому 1918 р. (Ф. 1115. Оп. 1. Спр. 74. Арк. 59).
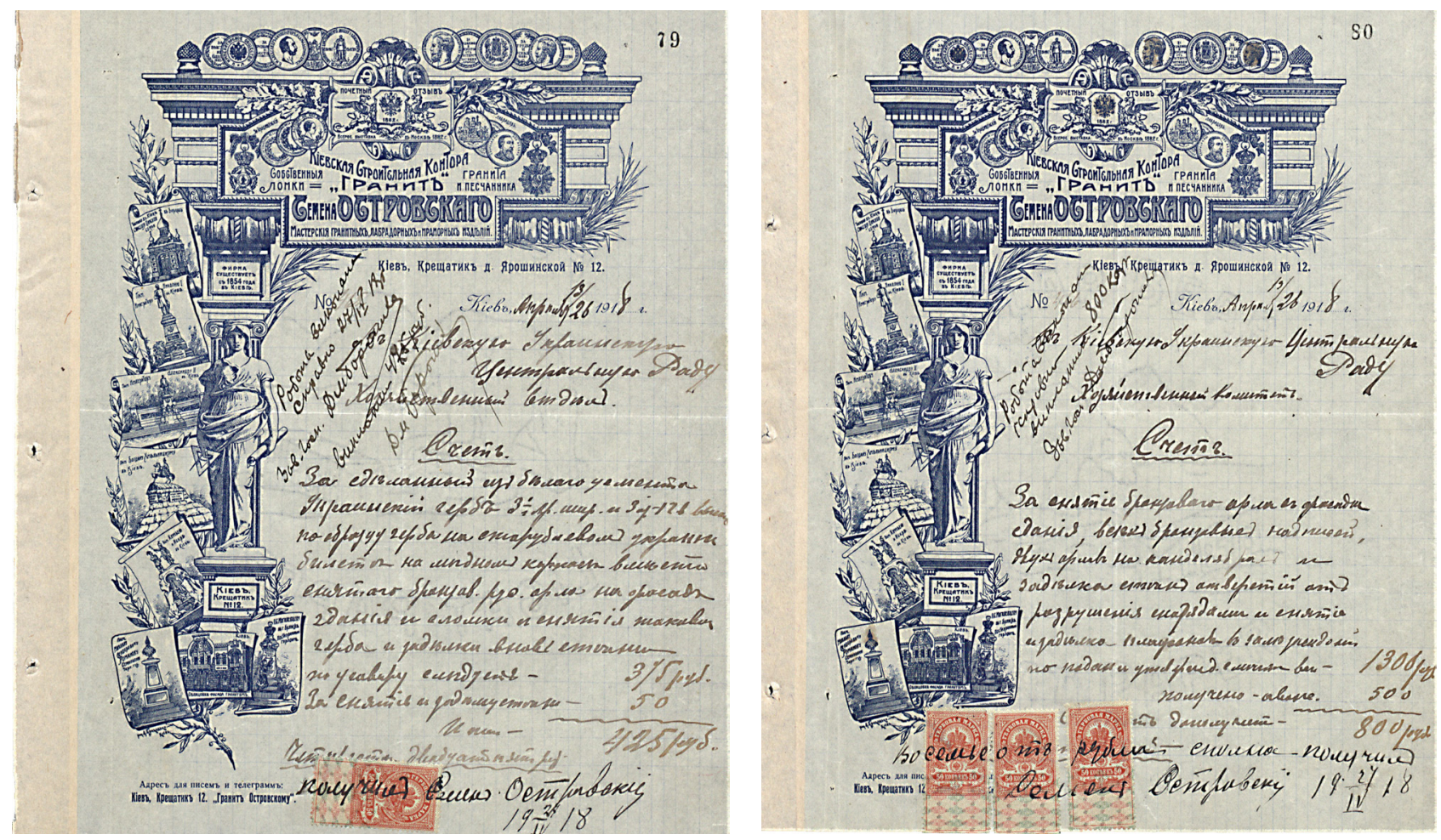

Рахунки Київської будівельної контори «Граніт» для УЦР за вироблення цементного

Українського гербу та зняття бронзового орла і ремонт будинку після попадання в нього снарядів ЦДАВО Украӥни, Ф. 1115. On. 1. Спр. 73. Арк. 79, 80

Рахунок Київського міського електричного підприємства за споживання електроенергії Українською Центральною Радою в січні-лютому 1918 р. ЦДАВО України. Ф. 1115. On. 1. Спр. 74. Арк. 59

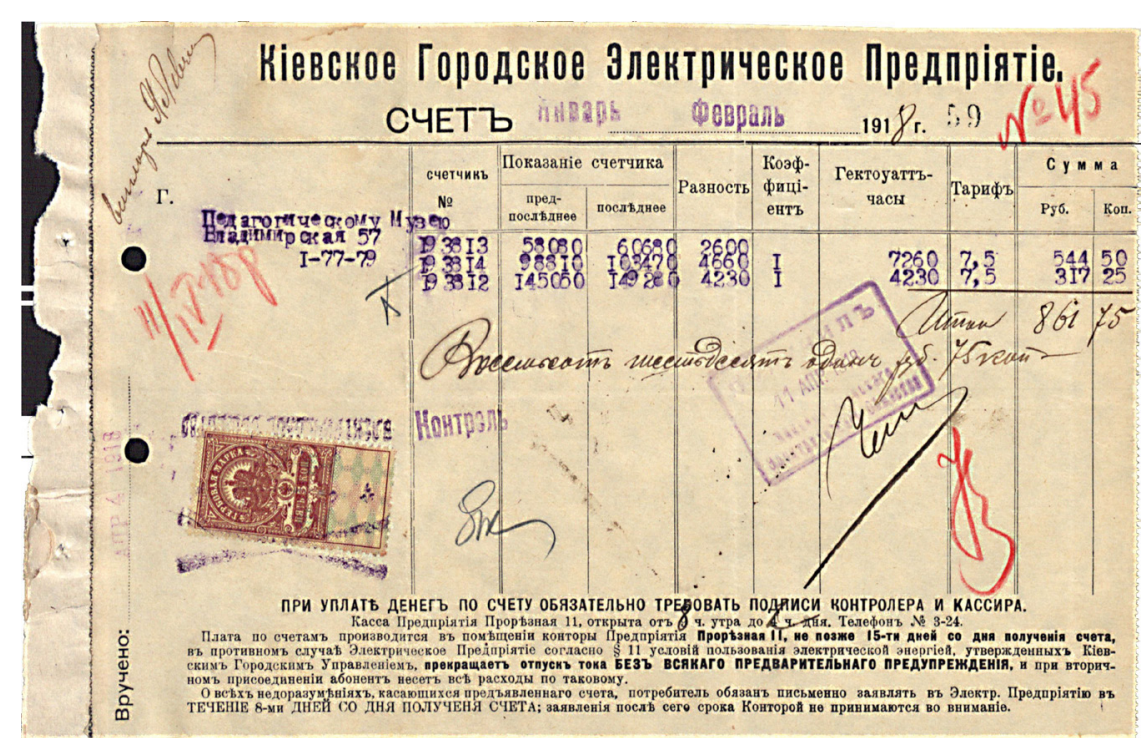




\section{ДЖЕРЕЛА ДО ІСТОРІї МІСТ}

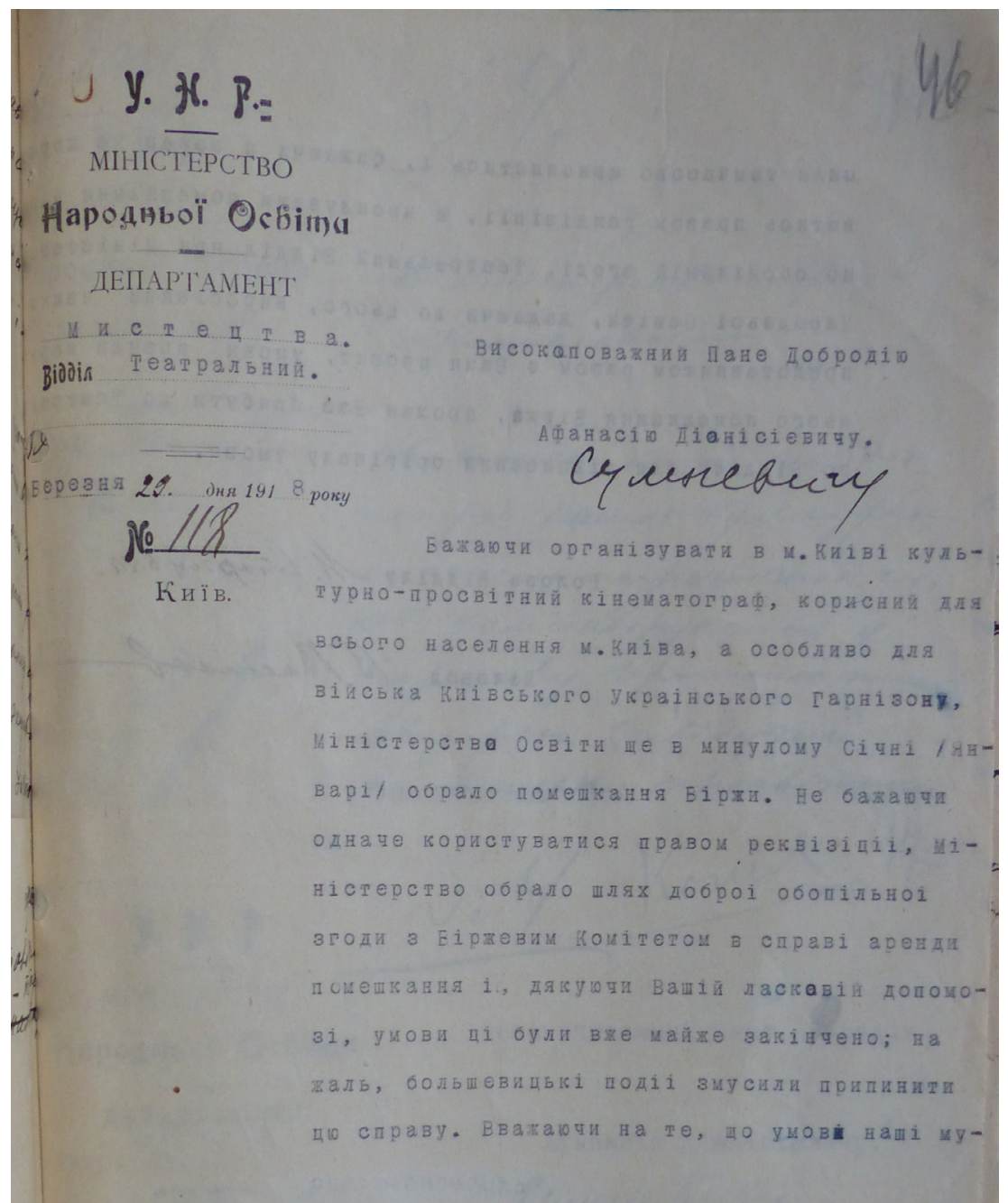

Лист голови театрального відділу департаменту мистецтва Міністерства народної освіти УНР М. Старицької

О. Сумневичу з проханням надати приміщення Біржи для організації культурно-

просвітного кінематографу. 29 березня $1918 \mathrm{p}$ ЦДАВО України. Ф. 2581. On. 1. Спр. 199. Арк. 46, 4636.

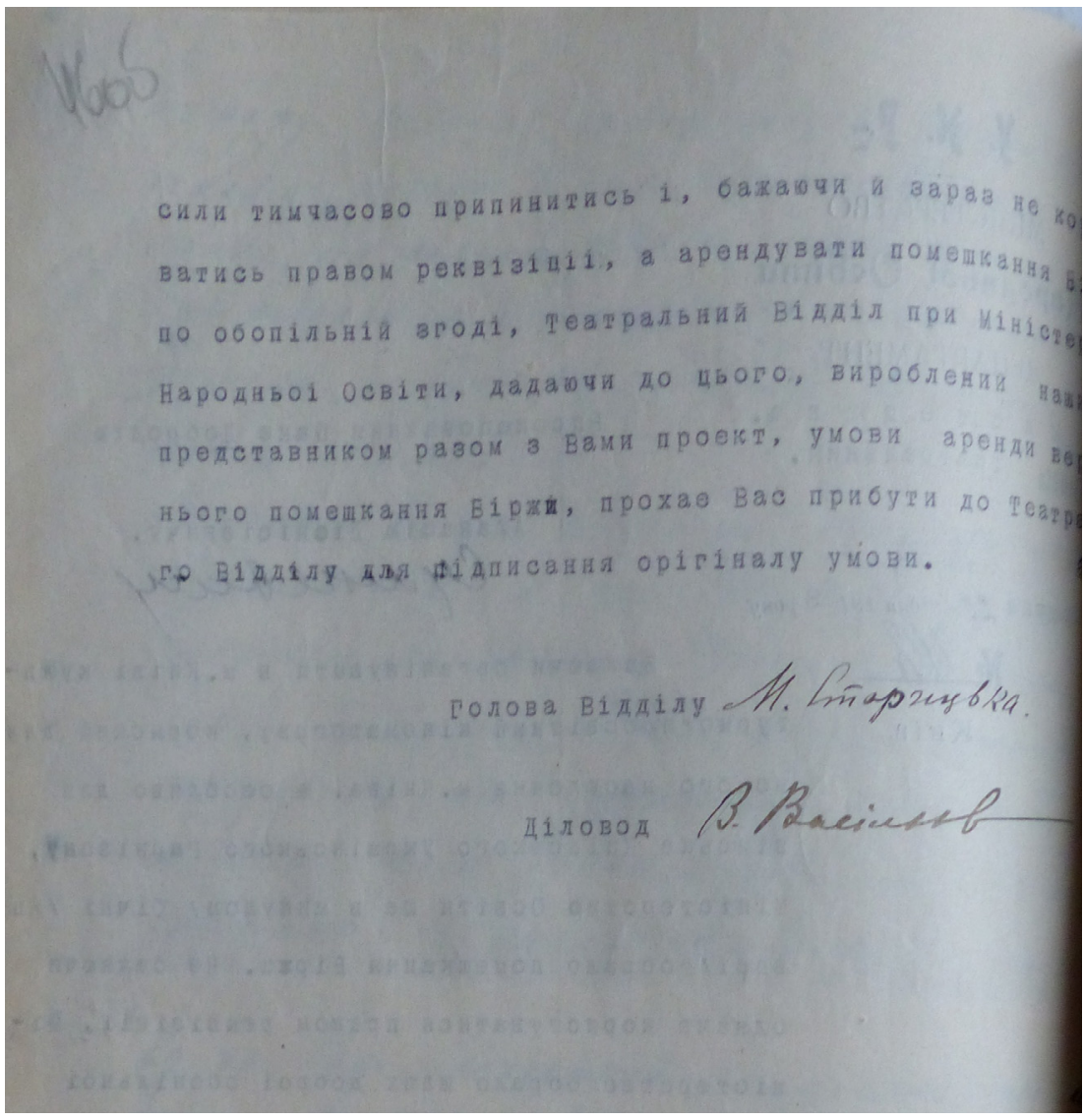




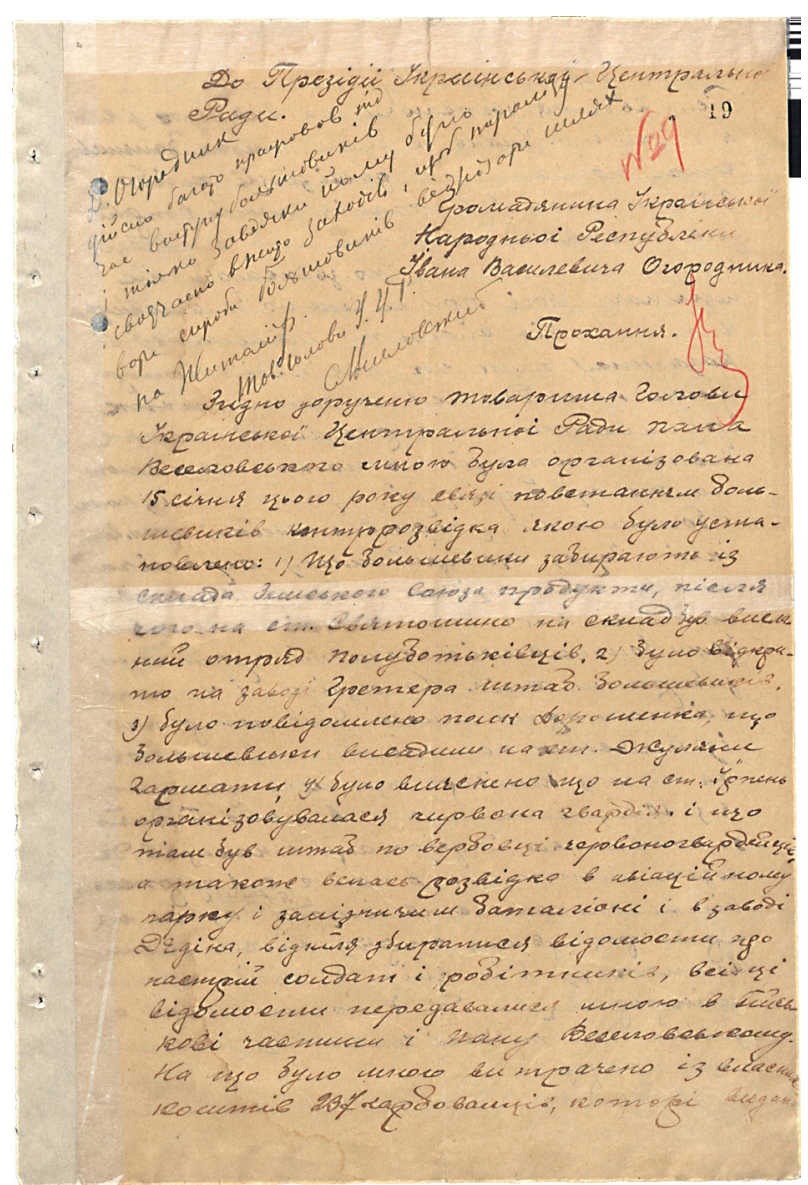

Звернення І. Огородника до Президії Української Центральної Ради про відшкодування коштів, витрачених ним на розвідку та агітацію проти більшовиків. 15 березня $1918 \mathrm{p}$. ЦДАВО України. Ф. 1115. On. 1. Спр. 74. Арк. 19, 19зв. 20
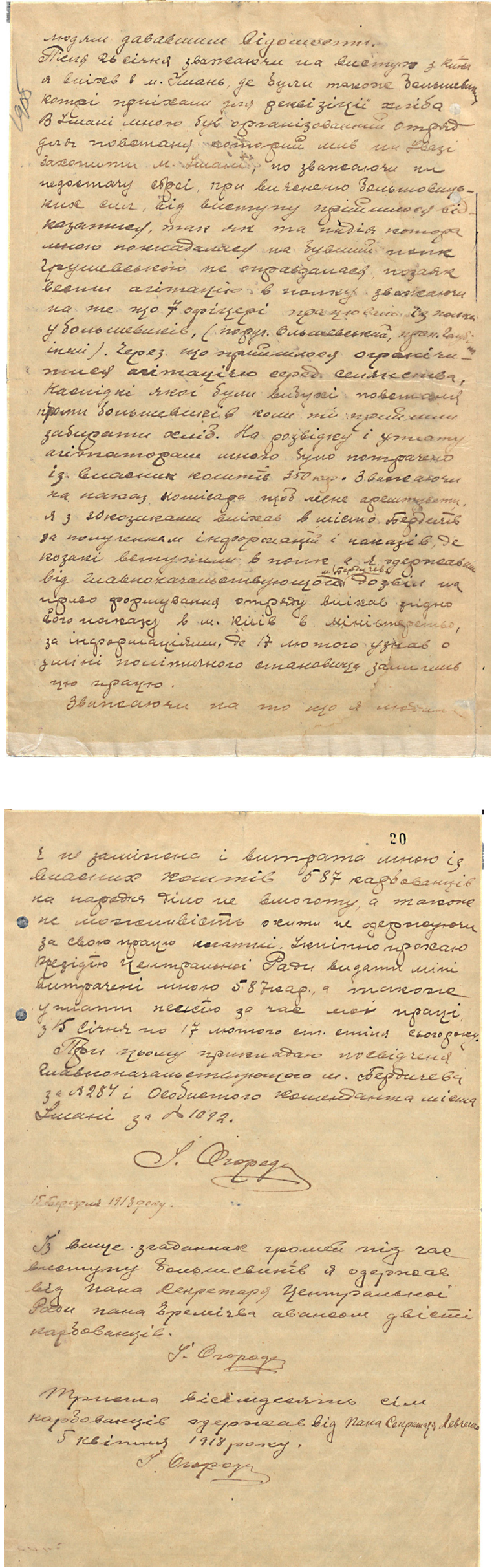


\section{ДЖЕРЕЛА ДО ІСТОРіÏ МІСТ}
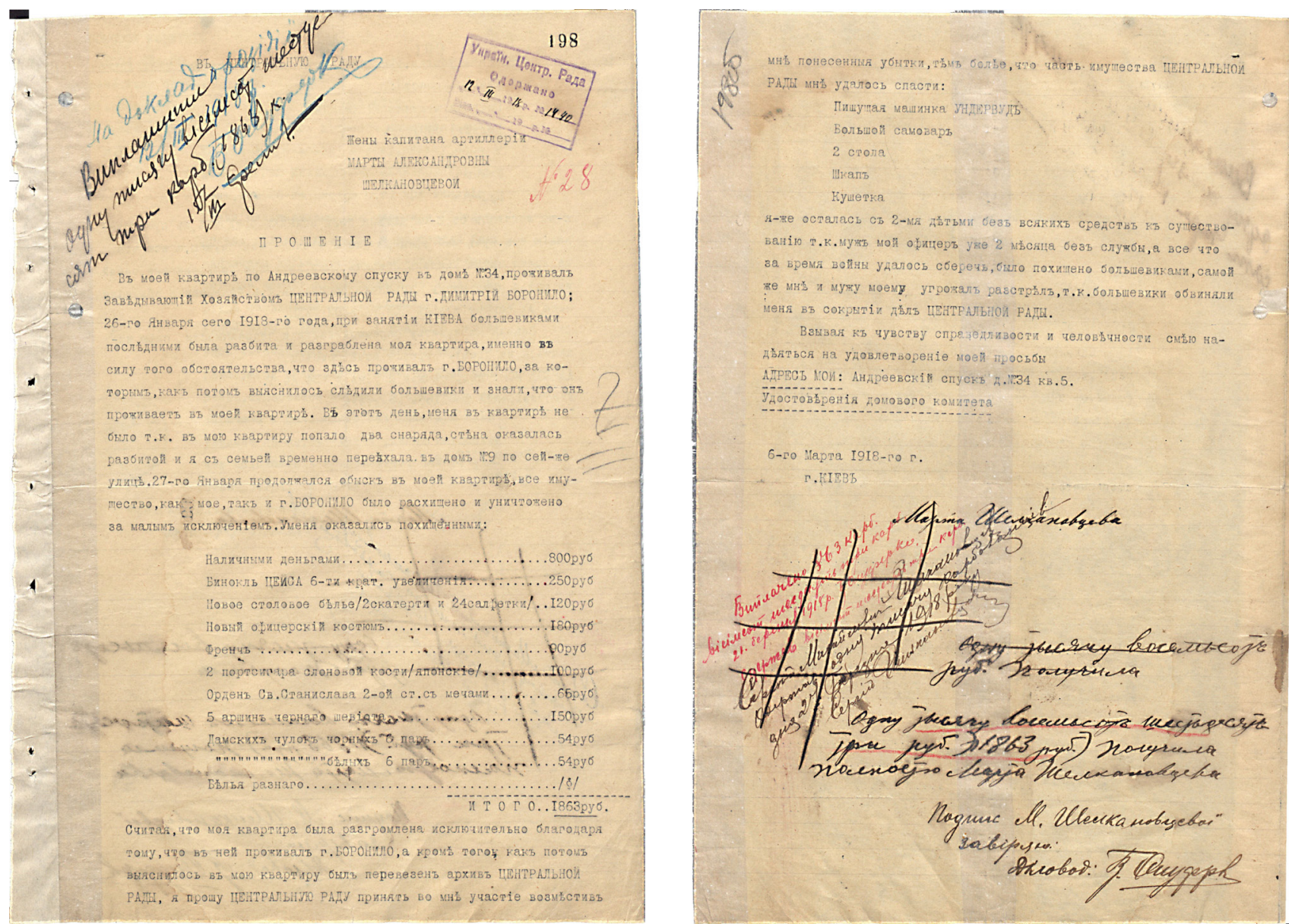

Прохання М. Шелкановцевої про відшкодування збитків, завданих більшовиками через проживання в ії помешканні завідувача господарством Української Центральної Ради Д. Боронила та посвідчення Домового комітету мешканців будинку № 34 Андріївського узвозу в Києві про грабіж. 6, 9 березня $1918 \mathrm{p}$.

ЦДАВО Украӥни. Ф. 1115. Оп. 1. Спр. 74. Арк. 198, 198 зв.

Прохання члена Малої Ради I. Довгого про виплату жалування за січень 1918 р. у розмірі 90 крб. 8 березня $1918 \mathrm{p}$. ЦДАВО Украӥни. Ф.1115. On.1. Спр. 74. Арк. 192

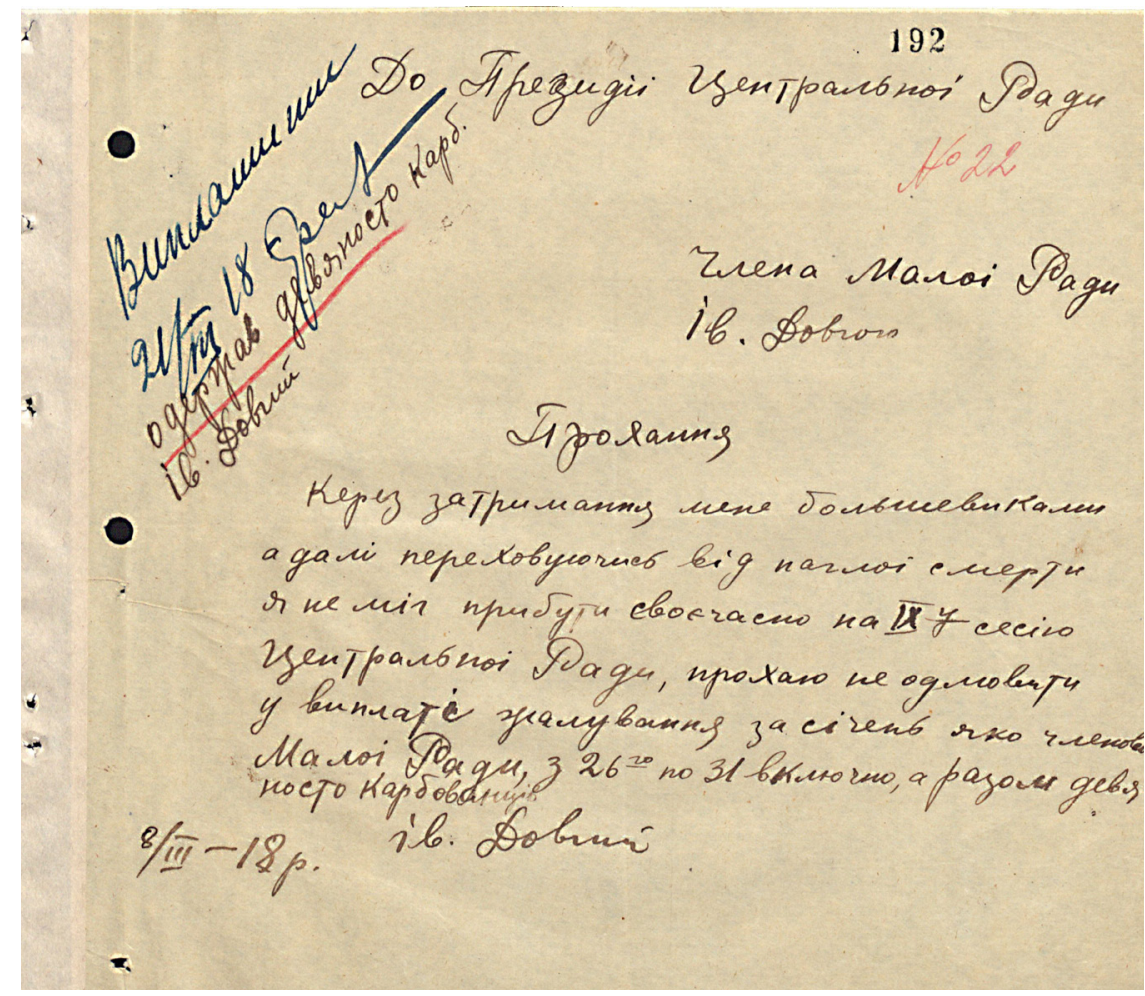



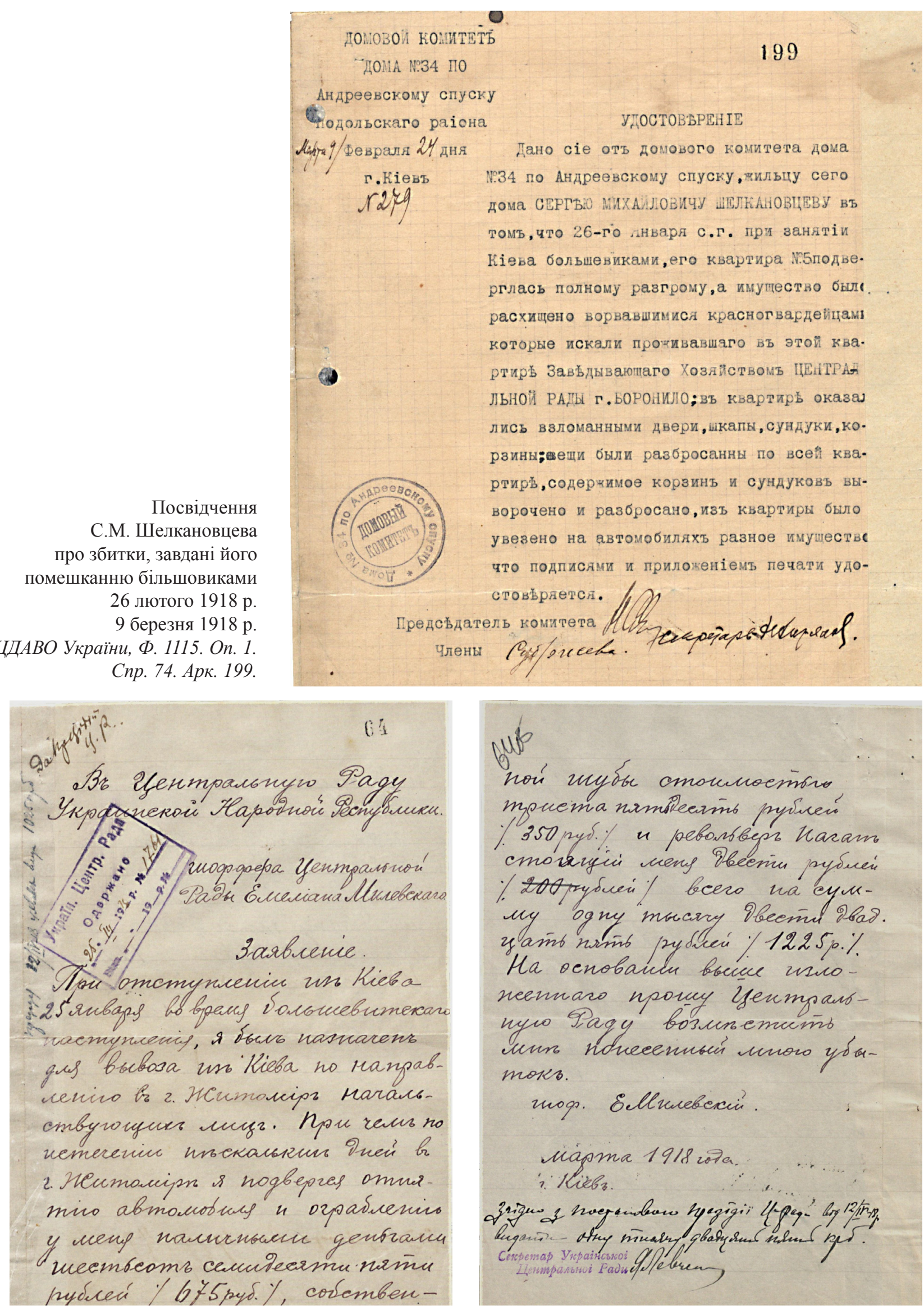

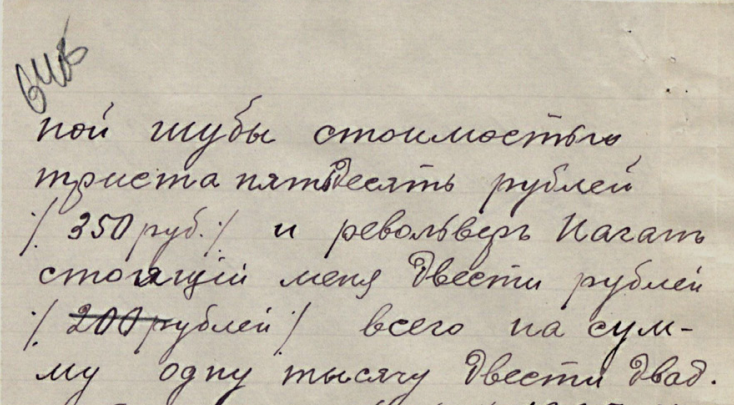

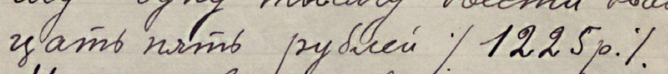
Ha oenobaulu bocice usuconeenmaro nponcy yenmpansnyo Pagy bosunemciño unr noneeenubí movo yó mores.

mogs. Eellwaberin.

$$
\text { Magma } 1918 \text { zola. }
$$

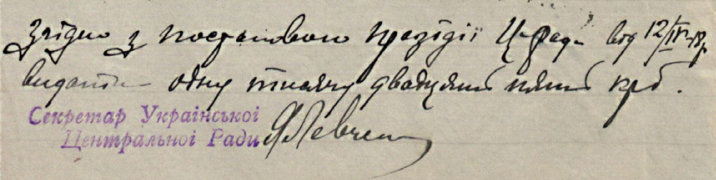

Заява шофера Української Центральної Ради О. Милевського про відшкодування збитків, завданих йому після від'іззду керівництва УЦР з Києва до Житомира. 


\section{ДЖЕРЕЛА ДО ІСтоРІї МІСт}

Заява шофера УЦР О. Милевського про надання йому нагороди за вивезення

М. Грушеського з Києва під час більшовицького повстання. 11 квітня $1918 \mathrm{p}$. ЦДАВО України. Ф. 1115. On. 1.

Спр. 73. Арк. 92

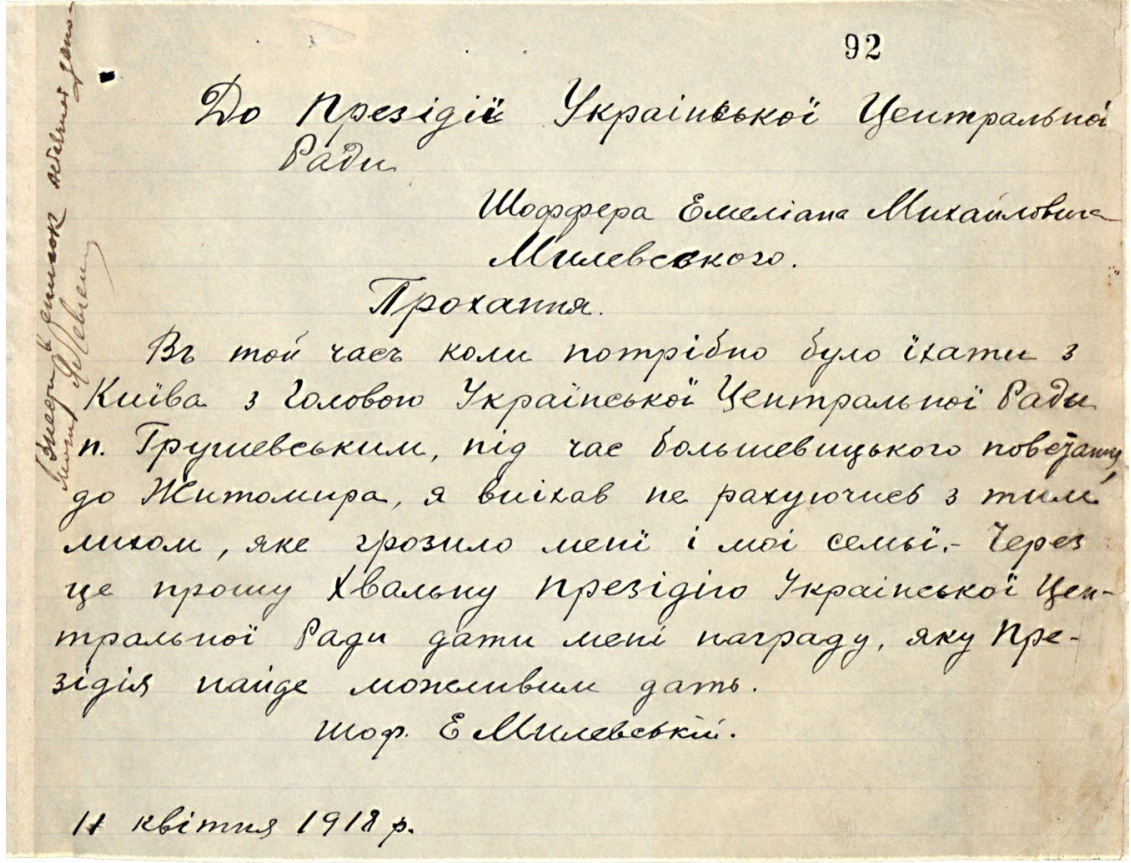

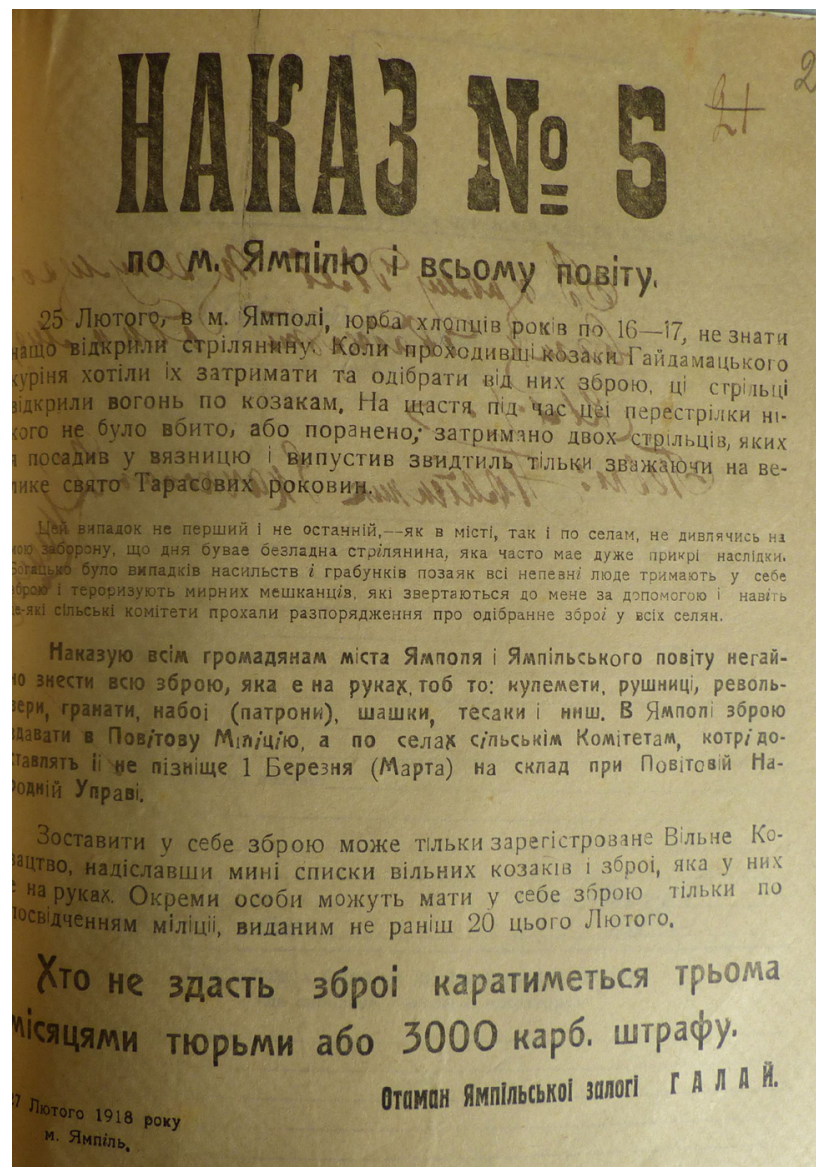

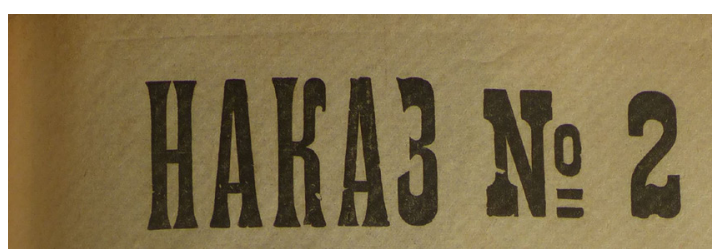

По запозі м. Ямпопя

$\S 1$.

Мною помічено, що в м. Ямпопі з'явпяеться що день то біпьше п'яних, котрі разповсюджують всякі брехні та несинітниці, що хвипюе насепення.

НАКАЗУЮ АБИ 3 ЧЬОГО ЧАСУ Я НЕ БАЧИВ НІ ОДНОГО П'яНОГО.

Кожен п'яний, хто 6 він не був, буде заарештований і притягнений до відповідапьности.

\section{\$ 2}

По всім иуткам міста Я мпопя часто чути якусъ безпадну стрілянину, яка турбуе мешканців і дае підставу дпя ріжних про овкаційних бапачок.

НАКАЗУФЮ АБИНА ДАПІ СТРІПЯ્ЯНИНА В МІСТ Н̈E ДОПУ ККАЛАСЬ.

Кошен, вй украінського війска.

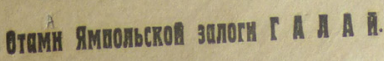

Накази отамана Ямпільської залоги про притягнення до відповідальності за пияцтво та використання зброї. 19, 25 лютого 1918 р. ЦДАВО Украӥни. Ф. 4585. On. 1. Спр. 13. Арк. 8, 20 